\title{
"Ndiyindoda" [I am a man]: theorising Xhosa masculinity
}

\author{
Sakhumzi Mfecane
}

Masculinity studies in South Africa depend on Western gender theories to frame research questions and fieldwork. This article argues that such theories offer a limited understanding of Xhosa constructions of masculinity. Xhosa notions of masculinity are embodied in the concept of indoda, meaning a traditionally circumcised person. This article explores the nuanced meanings of indoda and its relationship to other masculinities, like uncircumcised boys [inkwenkwe] and medically circumcised men. The discussion reveals that indoda is the most "honoured" form of masculinity. A traditionally circumcised individual is regarded as indoda, a real man, irrespective of his sexual orientation or class, and this affords him certain rights and privileges. Inkwenkwe and medically circumcised men embody "subordinate" forms of masculinity and are victims of stigma and discrimination by indoda. This requires us to revisit some Western theories of masculinity which place heterosexual men at the top of a masculine hierarchy and gay men at the bottom. It furthermore requires us to pay attention to the body when theorising Xhosa masculinity, since it is a principal way of "proving" and "defending" Xhosa manhood.

\section{Introduction}

This paper investigates constructions of masculinity among amaXhosa of South Africa. Xhosa notions of masculinity centre on the practice of ulwaluko, the customary rite of passage from boyhood to manhood (Ntombana 2011) undertaken by boys aged 18 years and older. Ulwaluko entails, among other things, circumcision followed by separation from society for a period of three to six weeks. During the separation period, the initiate - known as umkhwetha - lives in the secluded temporary ibhoma lodge together with a designated guardian called ikhankatha. This is where he receives instruction about being a man from the ikhankatha and other initiated male youths [abafana] (Ngwane 2004).

After the completion of the ulwaluko ritual, a Xhosa initiate is reintegrated into the community and officially regarded as a man, an indoda. This allows him to marry, build a homestead and actively participate in community discussions and rituals (Ntombana 2011). Uncircumcised Xhosa- speaking males are generally referred to as boys, amakhwenkwe, irrespective of their age or social status. They are not allowed to marry or perform rituals. Medically circumcised men are equally viewed as being inferior to traditionally circumcised men and given negative labels (Peltzer and Kanta 2009; Mavundla et al. 2010). 
Although much has been written about ulwaluko, it is largely descriptive and focussed on problems associated with the ritual like deaths, injuries, crime and gender oppression (Bogopa 2007; Kepe 2010; Mavundla et al. 2010; Peltzer and Kanta 2009; Venter 2011; Vincent 2008). There has been no scholarly attempt to explore the implications of ulwaluko for theorising masculinity. This paper, in contrast, argues that ulwaluko and the associated concept of indoda represents a version of masculinity that does not fully conform to the established theories of masculinity from the Global North, ${ }^{1}$ particularly their conceptualisation of embodiment and masculine hierarchies. Thus my goal is to bring out the theoretical implications of the concept of indoda as an attempt to develop an Africancentred theory of masculinity. This paper contributes to current debates which call for "world-centred" rather than "metropole-centred" theories of masculinity (Connell 2014; Jackson and Balaji 2001).

The significance of this discussion for South African research on men and masculinities is that it counters the problem of "academic dependency" identified by Syed Farid Alatas as a key feature of scholarship from the Third World. He defines it as "a condition in which the social sciences of certain countries are conditioned by the development and growth of the social sciences of other countries to which the former is subjected" (Alatas 2003, 603). South African research on men and masculinities has been characterised by academic dependence on the West to provide theories of masculinity upon which research questions and empirical research are based. My discussion of the concept of indoda addresses this knowledge gap.

I begin by explaining the relevance of theory in masculinity research. I then discuss the problem of academic dependence as it manifests in masculinity scholarship in South Africa. Following from this, I briefly outline the basic theories of masculinity, with specific focus on "hegemonic masculinity." The paper then explores ulwaluko and its implications for theorising embodiment and masculine hierarches. I conclude by linking this discussion to gender activism.

\section{Theory in social research}

Social theories are general assumptions and propositions about the nature of social life. These assumptions and propositions generally shape the way social research is conducted, including research questions, methods of enquiry, interpretation of data and interventions. The most common feature of contemporary social science theories is that they originate from the West, specifically France, the United States of America and Great Britain (Alatas 2003, 602). The academic "field" in general has been characterised by an unequal "division of labour" (605) among scholars, whereby the West serves as a centre for theorising and the Third World is where raw data is collected that is later theorised and published in Western academic journals (Alatas 2000; Nyamnjoh 2012a; Comaroff and Comaroff 2012). According to Syed Farid Alatas (2003, 604),

There is hardly any original metatheoretical or theoretical analysis emerging from the Third World. While there is a significant amount of empirical work generated in the Third World[,] 
much of this takes its cues from research in the West in terms of research agenda, theoretical perspectives and methods.

This division of labour "functions to perpetuate academic neo-colonialism and dependency" (Alatas 2003, 608). Perhaps the most significant problem that it creates for masculinity studies is noted by Connell $(2007,46)$ when she states:

Social theory is built in dialogue with empirical knowledge or sometimes derived from the theorist's own research, more often other peoples. When that empirical knowledge derives wholly or mainly from the metropole, and where the theorists' concerns arise from problems of metropolitan society, the effect is erasure of the experience of the majority of the human kind from the foundation of social thought.

Contemporary masculinity theories are characterised by this "erasure" of the experience of the majority of men from their foundation. Founded in the West, masculinity theories generally reflect the experiences and "concerns" of their societies (see, for example, Pleck 1987; Kimmel and Messner 2001; Herek 1986; Carrigan, Connell, and Lee 1985; Connell 1987). The theories have emerged out of dialogues in Western society between masculinity scholars, feminists and gay liberation movements (Carrigan, Connell, and Lee 1985). The dialogues emerged out of concerns over the oppression of women and gay men by heterosexual men and the changing social positions of men and women (Carrigan, Connell, and Lee 1985; Pleck 1987). While these concerns resonate with other societies in the world, it cannot be assumed that the theories designed to address them are universally applicable. Social life varies according to different cultural beliefs, class, race and other variables. This gives rise to the need to construct theories of masculinity that reflect varied life experiences.

South Africa is a suitable place for theorising the diversity of masculinities. There are 11 different official languages and all of them use distinct concepts and idioms to refer to men. These idioms embody different ways of being a man; they are not mere language differences between various ethnic groups. Currently, there is a lack of masculinity theories that speak to these diverse concepts and idioms. Before I discuss the concept of indoda as an example of an African-centred theory of masculinity, I briefly look at some definitions of masculinity in the literature on gender.

\section{Defining masculinity}

Masculinity refers to practices associated with being a real man. Contemporary theories of masculinity adopt a social construction paradigm (Herek 1986, 567) and they are premised on the belief that "men are not born; they are made" (Ougzane 2006, 2; Kimmel and Messner 2001, xv). Therefore, "the idea of masculinity is not merely biological outside of time. It is not simply given with men's bodies, male genes or hormones, or possession of a penis" (Ratele 2013, 145). Masculinity is something that people achieve through established "manhood acts" which are read socially as representing manliness in a particular historical period (Schrock and Schwalbe 2009). Under these conditions, performances of masculinity 
are not limited to male bodies; women too are capable of performing "manhood acts" under given social circumstances (Schrock and Schwalbe 2009).

The most influential theory of masculinity in contemporary gender scholarship is offered by Raewyn Connell $(1987,1995)$. Connell's theory of gender originated as a critique of sex role theory, in particular its limited theorisation of gender power and change as an internally generated affair (Demetriou 2001). It draws attention to the multiplicity of masculinities, noting that in each society there are multiple forms of masculinity at any particular time. Hegemonic masculinity, as the most "honored" (Connell and Messerschmidt 2005, 832) way of being a man, gains ascendency through persuasion and force (if needed) and becomes a model for judging what it means to be a real man.

Hegemonic masculinity is largely regarded as a "theory of Western gender order" (Demetriou 2001, 341). This raises the question: what are non-Western theories of masculinity? It cannot be assumed that Western models of masculinity apply equally to non-Western contexts, as societies differ culturally and historically (Jackson and Balaji 2001). Thus the primary goal of this paper is to examine the concept of indoda and its implications for theorising masculinity from an African perspective. The goal is not to question the validity of established Western masculinity theories; that would be an impossible task given their strong support in Western society and beyond (Connell and Messerschmidt 2005). Instead, following Jackson and Balaji (2001, 22), I ask, "What makes a man who he is within his culture?" The significance of this question is that it allows for an exploration of multiple meanings of being a man and possible new angles for theorising masculinity.

This discussion is based on the intimate encounter with and experience of ulwaluko rituals over several decades as an adult Xhosa-speaking man. I underwent ulwaluko myself to become an indoda, a man. This was not my first encounter with ulwaluko. As a boy [inkwenkwe], I participated in social activities associated with ulwaluko rituals and slept in the ibhoma together with the initiates. I did not conduct formal research on ulwaluko in order to write this paper; it is rather based on my observations during and participation in the ritual. To support my argument, I have drawn on numerous published studies about ulwaluko, including academic papers, fiction and biographies. However, not all the sources I used have "evidence" for the claims that I want to make. Moreover, some of my ideas are speculative and meant to stimulate debate rather than provide a factual account.

\section{Theorising the body}

When a Xhosa-speaking person undergoes ulwaluko, he is told to shout "Ndiyindoda!" [I am a man] immediately after the removal of his foreskin (see Mandela 1995). This declaration marks a significant shift in his social status. He is no longer an inkwenkwe, although he is not completely regarded as indoda until he has fully completed the ritual. The transition from boyhood to manhood thus begins with a specific act of inserting a cultural mark of manhood into the body (Ngwane 2004). As soon as a Xhosa initiate is re-integrated into the community as an indoda after weeks of separation, his manhood status [ubudoda] is judged less by having a circumcised penis and more by his public conduct: dress code, responsibility, 
respect and avoidance of violence. When this conduct is displayed by an uninitiated person, it does not make him indoda. It has to be preceded by circumcision in order to be regarded as a sign of being a man.

In cases where the behaviour of an initiated person is contrary to his manly status, for example because of criminal acts, violence or disrespect, he does not lose his status as an indoda. The social fact of having undergone ulwaluko to completion means that he remains an indoda, even if he violates the expected social conduct. This implies that the ubudoda manhood status among amaXhosa is grounded primarily in the physical body (penis). Not only does the penis serve as a site for the symbolic location of manhood status, it is a medium through which men can "validate" and "defend" their manhood status in times of need (Vincent 2008).

The imperative to defend or validate manhood status stems from the fact that information about ulwaluko is a closely guarded secret (Soga 1931). To ensure that those who have not undergone ulwaluko do not pass as amadoda, amaXhosa devised a special language of communication among amadoda which is imparted to traditionally circumcised Xhosa initiates during the separation period (Mgqolozana 2009). It is through this special language that boys and men who were circumcised in hospital are excluded from the "circle of legitimacy" (Connell 1995, 79), referred to as esidodeni in isiXhosa. Initiates are required to memorise this language since it serves as admission criteria into ritual spaces.

The following extract illustrates these acts of validation and the consequences of trying to pass as an indoda. The speaker is a young Xhosa-speaking male who visited a tavern reserved for amadoda, pretending to be an indoda.

I once broke the rules applying to entrance into a tavern. No boys were allowed entrance. On this day I pretended to be a man and was allowed to join the others inside this tavern. After two to three hours I went to the toilet to relieve myself. I did not notice that the tavern owner followed me. He confronted me and instructed me to produce proof that I am a circumcised man. I tried delaying tactics but to no avail. He called other men who started kicking and punching me all over my body, and I was dragged outside the tavern yard. (Mavundla et al. 2010,4)

Xhosa-speaking men are not required to produce proof of circumcision status every time they enter a social space. Rather, because of the publicness of the ceremonies which celebrate the completion of the ulwaluko ritual, called umgidi (see Ngwane 2004), each person's manhood status is known to community members who are able to recall his period of ulwaluko. When a person's period of undergoing ulwaluko is not publicly known and others are suspicious of his manhood status, he may be required to defend his manhood through the language of manhood (Mgqolozana 2009). When it happens that a Xhosaspeaking man is unable to defend his manhood status through these speech codes, he is obliged to strip off and allow other men to inspect his penis (Vincent 2008). Usually this is embarrassing because it suggests that the person did not internalise the education imparted 
during ulwaluko. Listening and memorising are key features of being an indoda. Nonetheless, in times of need, inspection can serve as the only available means of defending one's indoda status. It can be the difference between expulsion from "the circle of legitimacy" and being recognised as a real man.

Further illustration of this inspection and verification of the status as an indoda is provided by novelist Zakes Mda in his celebrated work entitled The Heart of Redness (2000). The novel is set in the aftermath of South Africa's first democratic elections and is located at the place where the Xhosa cattle killing disaster occurred (Peires 1989). The protagonist, a middle-aged male called Camagu, spent 20 years in exile and then returns to live alone in Johannesburg. After trying in vain to find a woman he was smitten with in Qolora in the Eastern Cape Province, Camagu decides to remain there. The community is divided between those who support government plans for development (the Unbelievers) and those who are opposed to it (the Believers). At a community meeting, Camagu, who sides with the Believers, becomes involved in a heated debate about the development plans with Bhonco, a staunch Unbeliever, when he makes a strong case for the Believers and appears to gain public support. Out of desperation, Bhonco accuses Camagu of being uncircumcised.

"This son of Cesane, I ask you, my people, is he circumcised? Are we going to listen to uncircumcised boys here?"

"How do you know he is not circumcised?" asks Zim [a Believer]. "Why should that matter?" says Camagu. ...

"You said you respected our customs," says Bhonco. "So you respect them only when it suits you? Clearly you are uncircumcised!"

"I challenge you, Tat'uBhonco, to come and inspect me here in public to see if I have a foreskin," says Camagu confidently. He knows that no one will dare take up that challenge. And if at any time they did, they would not find any foreskin. He was circumcised, albeit in the most unrespectable manner, at the hospital. Zim's supporters applaud. (Mda 2000, 202)

I will deal with medical circumcision later. What is of significance here is that Camagu's status as a man is temporarily put in doubt until he boldly volunteers to be publicly inspected. The public doubt about his manhood status stems from the fact that Camagu's personal biography is unknown in Qolora because he grew up overseas. The act of inspection speaks to the significant role of the body in Xhosa performances of masculinity.

Contemporary theories of masculinity regard the body, thus the material reality, as a key constituent of gender identity after second-wave feminists had refused it analytical utility because of its association with essentialist notions of gender (Davis 1997; Woodward 2001; Ortner 1974). Bodies in contemporary masculinity theory are no longer treated as mere cultural constructions and passive outcomes of discourse (Connell 1995). They are viewed as active players in everyday performances of gender (Swain 2003). It is through the body that individuals experience manhood (Connell 1995, 54) or feel emasculated when they feel they do not embody "proper" masculine attributes, for example disabled men (Gibson et al. 2007). Thus, several scholars of masculinity have focussed on issues such as physical size, 
exercise, health and sport as ways in which masculinity is embodied and enacted in everyday life (Gremillion 2005).

An interesting problem raised by Connell and Messerschmidt $(2005,851)$ is that "the pattern of hegemony involved in embodiment has not been convincingly theorized." It is perhaps in relation to this knowledge gap that this discussion of the concept of indoda makes a novel contribution to masculinity theories. Hegemony in the indoda discourse is primarily achieved by having a traditionally circumcised penis. It is a principal way of proving that an individual is a real man. From the time that a person undergoes circumcision until he fully recovers and is integrated into the community as indoda, his ubudoda manhood character is tested and pushed to the limits. To shout "ndiyindoda" immediately after circumcision is to accept a challenge to prove it through ukusebenza [hard work] centred on the penis and personal discipline. Thus, the status of being an indoda is not simply an outcome of a passive body, namely the circumcised penis. It "result[s] from a sustained, active engagement with the demands of the intuitional setting" (Connell 2001, 57).

Under these circumstances, medically circumcised men are not considered as part of the circle of legitimacy because they represent cowardice [ubugwala], an unmanly characteristic. Their "medicalised" penises are a sign of their unmanly character. The circumcised body of a Xhosa- speaking person, however, is not a stable, fixed entity. From the moment a person is circumcised, he enters a liminal stage characterised by uncertainty about his future as a man. Injuries and penile amputations may occur during this ritual (Kepe 2010), producing the types of bodies that are capable of disrupting the established social order. The concept of "recalcitrant" bodies (Connell 1995, 58) is instructive here. It implies that bodies have agency. When they refuse to be subjected to the "social arrangements into which they are invited" (Connell 1995, 58), it is likely to lead to a "crisis" of masculinity (Woodward 2001). Thus, in present-day Xhosa society, the idea of being a man - an indoda - is highly uncertain. It can no longer be assumed that those who have undergone ulwaluko to completion qualify as amadoda (Mgqolozana 2009). What if they have deformed penises or none at all? Does the experience of pain and acquisition of the "language of manhood" suffice to make them amadoda? These are some of the questions that require further research.

\section{(Re)theorising masculine hierarchies}

Multiple forms of masculinity exist in any given cultural context. Connell (1995) offered a model for theorising the relations between these masculinities through the concepts of hegemonic, subordinate, marginal and complicit masculinities. These concepts capture the relations of power between groups of men in the Western gender order (Connell 1995, 77). The model ranks heterosexual men as highest in, and homosexual men at the "bottom of [the] gender hierarchy among men" (Connell 1995, 78). The basic premise of this model is that men as a group are more privileged than women. Thus, one of the critiques of this model is that it is premised on the "feminist principle" (Demetriou 2001, 343) that gives analytical priority to the oppression of women by heterosexual men (external hegemony) and less attention to oppression among men (internal hegemony). 
In South Africa, Connell's model of masculinities is used to identify differences among various groups of men ordered by race, class and culture (Morrell 1998). My assessment of the use of this model in South Africa is that scholars seem to overlook a crucial qualification made by Connell: that her model of masculinities represents "patterns of masculinity in the current Western gender order" (Connell 1995, 77). Many research findings and statements simply repeat Connell's theoretical claims on the low placement of homosexual men. For example, in writing about masculinity in South Africa, Swart (2001, 76-77) explains:

In South Africa there are multiple definitions of masculinity - with dynamic hierarchies of identity. Different masculinities do not earn equal social respect. Some are actively dishonoured (like homosexuality), some are exemplary (like sporting heroes), and some are socially marginalised.

Similarly, Jewkes et al. (2015, S113) state:

A core element of the construction of hegemonic masculinity is heterosexuality, and to a greater or lesser extent hegemonic masculinity is constructed as a gender position that is as much "not gay" as it is "not female."

These statements exemplify a scenario that Syed Hussein Alatas (2000, 37) calls the "captive mind": "one that is imitative and uncreative and whose thinking is based on Western categories and modes of thought." I do not wish to deny that homosexuality is the most subordinated form of masculinity in South Africa. Derogative concepts used to refer to homosexual men worldwide are applicable here as elsewhere and find expression in various South African languages (Msibi 2013; Ratele 2011). They give support to the claim that the key feature of hegemonic masculinity is that it is homophobic (Herek 1986; Kimmel 1994, 131; Talbot and Quayle 2010). Yet, among amaXhosa, the relevance of this model is subject to debates and contestations and it would be misleading to treat Connell's model of masculine hierarchies as having universal applicability.

Within ulwaluko discourse, being indoda represents hegemony since it is the most honoured way of being a man. Being indoda is generally characterised by dominance and oppressive practices towards other masculinities. For example, uncircumcised adults and medically circumcised males are lumped together as "boys" and given derogative labels (Peltzer and Kanta 2009). Yet, there are major differences between masculine hierarchies represented in Western gender order and those ordered by indoda. The masculine hierarchies that indoda orders are not based on sexual orientation; rather they are based on circumcision status. A person does not necessarily need to be heterosexual to be regarded as indoda. This status can also be equally assigned to gay men on condition that they undertook ulwaluko. Thus, the most subordinated forms of masculinity in Xhosa gender order are uncircumcised adult men and medically circumcised men. This is supported by Mavundla et al. (2010, 937) who state: "When uninitiated Xhosa males are labeled, 
stereotyped, and set apart, a rationale is constructed for devaluing, marginalizing, and ostracizing them. The consequence of this is a downward placement on the social hierarchy."

There has been no research on uninitiated Xhosa-speaking adult men, possibly because the social stigma attached to it would make it difficult for both circumcised and uncircumcised researchers to get access to data. Yet, to support my argument about their subordinated status, I refer to an old story about Tiyo Soga, the only publicised case of an openly uncircumcised Xhosa- speaking adult. Tiyo Soga (1829-1871) was "the first black South African to be internationally educated and ordained as a minister" (Nxasana 2011, 64). After his parents were exposed to Christianity, they allowed him to be raised by a Scottish Presbyterian missionary, Reverend Thomas Chalmers. In keeping with Christian values, Tiyo Soga was not circumcised (Ndletyana 2008, 18). When war broke out in the Eastern Cape in 1846, Reverend Chalmers fled back to Scotland, taking Soga and three white youths with him. Soga undertook theological training in Glasgow and was baptised on May 7, 1848. After a short stint in South Africa, teaching at Uniondale Mission School in Keiskammahoek, he returned to Scotland in 1850 to study for the ministry and was ordained as a minister of the United Presbyterian Church on 23 December 1858. Soga married a Scottish woman named Janet Burnside and they returned to work among amaXhosa as missionaries (Soga 1983).

Soga embodied the characteristic features of hegemonic masculinity described by Connell $(1987,186)$ : "the most important feature of contemporary hegemonic masculinity is that it is heterosexual, being closely connected to the institution of marriage." Soga was heterosexual, married and had six children (Soga 1983). Yet, among the amaXhosa, Soga was not considered an indoda; he remained inkwenkwe because he never underwent ulwaluko. His status as inkwenkwe, however, created major barriers between Soga and amaXhosa throughout his life. Williams $(1978,12)$ explains that, at Lovedale Seminary, Soga

... seemed to have got on well with white pupils; the Blacks were less accommodating. Tiyo Soga was a quiet, gentle, "docile" lad who seems to have been the object of spite on the part of black pupils. The reason for this animosity may be associated with the fact that he was uncircumcised.

At the Uniondale mission station, Soga "ran into opposition from those who believed he should have been circumcised" (Soga 1983, 2). According to Ross (2009, 10), "[w]hen they heard this [that Soga was not circumcised], the Uniondale fathers took their sons away from Tiyo's school and some young men threatened to harm him if he did not submit to circumcision." At the Mgwali mission station, Soga's missionary work often clashed with Xhosa "Nativism." He was widely seen as a "traitor" for having shunned ulwaluko and preaching vehemently against Xhosa customs (Williams 1978, 84).

While this story is old, it is relevant because it confirms that among amaXhosa masculine hierarchies are based primarily on circumcision status. Unlike Western society, where "what a person does sexually defines who the person is" (Herek 1986, 568), it is one's 
circumcision status that defines who one is in Xhosa society. Thus, Soga was socially defined as a "boy" despite being educated, married and having children. This condition still applies among amaXhosa.

The subordination of medically circumcised men, in turn, is best illustrated by Zakes Mda (2013) in his biography. Mda, a leading fiction author in South Africa, went into exile when he was 16 years old to join his father and the founder of the Pan-Africanist Congress (Pogrund 1990). He underwent medical circumcision in Lesotho, aged 18 years. When he came back home from the hospital, his father organised a gathering of Xhosa-speaking men to give him words of wisdom - a practice called ukuyalwa. Mda $(2013,134)$ reflects on this encounter:

My father made such a big fuss about my circumcision, as if it had been the real McCoy traditional ritual and invited some relatives from Hershel who sat on my mother's Bradlows sofas and told me of responsibilities of manhood while they chewed meat noisily and drank Castle Lager. I knew this was a charade on their part, just to please my father; according to their customs and traditions I was nothing but a coward to have gone to the hospital for circumcision instead of roughing it up on the mountains where foreskins would be mutilated with a blunt instrument. But I didn't give a damn because my life was not with amaXhosa ... who still valued such customs and that in my view no longer had a place in the modern world, but with Basotho, whose educated class had long stopped the practice. In Lesotho only illiterates in rural areas continued with it.

Zakes Mda embodies the most valued attributes of hegemonic masculinity. $\mathrm{He}$ is a heterosexual man and married with five children (Mda 2013). Yet he concedes that amaXhosa would not regard him as a man because he did not undergo ulwaluko. As a result, he switched allegiance and identified with Basotho where his method of circumcision was irrelevant to his manhood identity. His situation is similar to that of Tiyo Soga. By Western standards of gender and on the basis of their class, independence and heterosexuality, these men should have occupied the highest ranking in the masculine hierarchy. But among amaXhosa, this was not the case.

The interesting question posed to indoda discourse concerns the position of gay men. Having undergone ulwaluko, gay amaXhosa are culturally entitled to be called indoda and to receive equal treatment as heterosexuals. This is because, culturally, there is no differentiation of sexuality when ulwaluko is conducted on amaXhosa boys. During an oral presentation of this paper in August 2015, a Xhosa-speaking man who identified himself as gay affirmed his indoda status when he said: "I visit traditional Xhosa rituals. I receive the same treatment as other men because I have undergone ulwaluko. I think the people who are expelled from the circle of manhood are amakhwenkwe and medically circumcised men." This interlocutor implied that what he "does sexually" has no bearing on his social status as a man. However, another interlocutor at the same presentation raised concerns about recent media reports of violence against a gay Xhosa-speaking man who was described as having been stripped naked, inspected and subsequently beaten up for being openly gay while being an indoda. This incident implies that the victim was perceived as not performing proper 
manhood acts (Schrock and Schwalbe 2008). It would thus seem that being gay on its own does not lead to a lower social placement in Xhosa masculine hierarchies. What appears to be paramount is that a person must be seen to conform to the expected social conduct of an indoda. ${ }^{2}$ Thus, in researching the placement of gay amaXhosa in masculine hierarchies, it is important not to assume that all gay men form a uniform group. It would be interesting to investigate whether gay indoda who are seen as conforming to heterosexual norms are more acceptable in the esidodeni circle of legitimacy compared to those who are seen as "feminine." Furthermore, in Msibi's $(2013,262)$ study, "linguistic harassment had to do with bodily performances and display"; those who are perceived as being manly are exempt from harassment compared to those who are judged to be effeminate.

\section{Some concluding remarks}

In advocating for an Africa-centred theory of masculinity, the objective of this paper is not to quarrel with established theories of masculinity developed in the Global North. Instead, I am seeking what Nyamnjoh (2012b, 148) calls "epistemological conviviality," a scenario whereby various knowledge systems are allowed to coexist, instead of one dominating the others. Masculinity theorising has indeed been dominated by knowledge and experiences of Western society (Connell 2014). It is only recently that experiences of masculinity from men in the Global South have been given prominence and allowed to form part of theorising on masculinities (Groes-Green 2012). However, this viewpoint on "prominence" is still provided by scholars based in the Global North and it perpetuates the scenario whereby the Global South is a reservoir of raw data to be exported for theorising and dissemination in Western academic journals (Alatas 2000). I chose to write about amaXhosa because of my close proximity to the society and the fact that I underwent ulwaluko; therefore I have a lived experience of the ritual. The notion that "native" scholars would put forward an authentic point of view is not relevant here (Narayan 1993, 682). What is relevant rather is that, in grappling with our complex social realities, various vantage points are needed. As an insider, I offer a special "angle of vision" (Comaroff and Comaroff 2012, 127) that differs from that of an outsider because of my positioning in this field of study. It is well possible that I have overlooked certain aspects of the ritual of ulwaluko that an outsider would find to be in need of deeper exploration than what I have granted them.

This exploration of ulwaluko has had two points of departure. Firstly, I argued that in theorising Xhosa masculinity we need to pay attention to the body since it is the principal way through which hegemony is achieved. This is evident in acts of penis "inspection" carried out on those Xhosa men whose ubudoda status is in doubt. The body here takes the form of "physical capital" (Wacquant 1995; Woodward 2011). Its size, strength, fitness and health are not relevant; what matters is that it has a tangible cultural mark of manhood which serves as an indicator of strength and the ability to withstand pain. Those who have medicalised bodies [amadoda asesibhedlele] or retain their foreskins are therefore considered "cowards" [amagwala] and unworthy of being called indoda. However, it cannot be assumed that those who undertook ulwaluko possess the penis "capital" because of incidents of penal amputations and injuries occurring in the bush. 3 
Secondly, I proposed that we need to revisit the typology of masculinities presented by Connell (1995) which places heterosexual men at the top of the masculine hierarchy and homosexual men at the bottom. This typology is distinctly Western (Connell 1995) which prompted me to ask: How are masculinities ranked in non-Western gender orders? I argued that masculine hierarchies among amaXhosa are based on the fact of circumcision instead of sexual orientation. This creates room for gay indoda to be included in the esidodeni circle of legitimacy. The argument about the inclusion of gay men in the circle of legitimacy remains speculative at this stage since there have been no empirical studies of gay indoda in South Africa.

This discussion has relevance for gender activism. It invites us to pay particular attention to "internal hegemony," not simply as a strategy for "external hegemony" (Demetriou 2001), but as an end in itself. Most gender activism in South Africa focuses on the oppression of women (and gay men) by heterosexual men (external hegemony). Yet, subtle and overt forms of oppression are regularly experienced by heterosexual uncircumcised men and medically circumcised men, posing a real threat to their lives (Peltzer and Kanta 2009; Mavundla et al. 2010). Many amaXhosa boys are forced to undergo ulwaluko against their will because of fear of the violence and social ostracism that may follow if they undertake medical male circumcision or remain uncircumcised. The physical and medical challenges of the ritual also lead to unwanted deaths and injuries happening in the bush, penis amputations and deformities. A human rights approach is needed to address these violent acts, but it must take into account the cultural imperative to undergo ulwaluko in order to be regarded as indoda.

\section{Notes}

1. The global North-South divide "names a structure of relations between the centre of economic power, military power and cultural authority in Western Europe and Northern America (Global North) and the rest of the world (Global South)" (Connell 2014, 218). While Global South countries are diverse, they share a history of colonisation and economic marginalisation in relation to the Global North. Scholars cited in this paper use the terms "Global South"/"Global North," "Third World" or the "West" to refer to these economic and geographic locations.

2. I thank Zethu Matebeni for this observation and for referring me to the relevant literature.

3.

In 2014, South Africa made news headlines as

the first country in which a successful penis transplant was conducted. The transplant was performed on a victim of a botched circumcision ("SA Doctors" 2015).

\section{Acknowledgements}

This paper was first presented at a seminar organised by the Institute for Humanities in Africa (HUMA), University of Cape Town. I would like to thank the participants for their critical comments and suggestions. I also thank Efua Prah, Zethu Matebeni and Mzulingile Gaqa for their comments and suggestions on the first draft of this paper. 


\section{References}

Alatas, S.F. 2003. "Academic Dependency and the Global Division of Labour in the Social Sciences." Current Sociology 51 (6): 599-613.

Alatas, S.H. 2000. "Intellectual Imperialism: Definition, Traits, and Problems." Southeast Asian Journal of Social Science 28 (1): 23-45.

Bogopa, D.L. 2007. "Challenges Facing the Initiation Schools: The Case of Nelson Mandela Metropole in the Eastern Cape." Acta Criminologica 20 (4): 55-60.

Carrigan, T., B. Connell, and J. Lee. 1985. "Toward a New Sociology of Masculinity." Theory and Society 14 (5): 551-604.

Comaroff, J., and J. Comaroff. 2012. "Theory from the South: Or, how Euro-America is Evolving Toward Africa." Anthropological Forum 22 (2): 113-131.

Connell, R. 1987. Gender and Power: Society, the Person and Sexual Politics. Standford: Standford University Press.

Connell, R. 1995. Masculinities. Cambridge: Polity Press.

Connell, R. 2001. "Masculinities and Globalization." In Men's Lives, edited by M.S. Kimmel, and M.A. Messner. 5th ed. Boston: Allyn and Bacon.

Connell, R. 2007. Southern Theory: The Global Dynamics of Knowledge in Social Science. Cambridge: Polity Press.

Connell, R. 2014. "Margin Becoming Centre: For a World-Centred Rethinking of Masculinities." Norma 9 (4): 217-231.

Connell, R., and J.W. Messerschmidt. 2005. "Hegemonic Masculinity: Rethinking the Concept." Gender and Society 19 (6): 829-859.

Davis, K. 1997. Embodied Practices: Feminist Perspectives on the Body. London: Sage.

Demetriou, D.Z. 2001. "Connell's Concept of Hegemonic Masculinity: A Critique." Theory and Society 30 (3): 337-361.

Gibson, B.E., N.L. Young, R.E.G. Upshur, and P. McKeever. 2007. "Men on the Margin: A Bourdieusian Examination of Living into Adulthood with Muscular Dystrophy." Social Science and Medicine 65 (3): 505-517.

Gremillion, H. 2005. “The Cultural Politics of Body Size.” Annual Review of Anthropology, no. 34: 13-32. Groes-Green, C. 2012. "Philogynous Masculinities: Contextualizing Alternative Manhood in Mozambique." Men and Masculinities 15 (2): 91-111.

Herek, G.M. 1986. "On Heterosexual Masculinity: Some Psychical Consequences of the Social Construction of Gender and Sexuality." American Behavioral Scientist 29 (5): $563-577$.

Jackson, R.L., and M. Balaji, eds. 2001. Global Masculinities and Manhood. Urbana: University of Illinois Press.

Jewkes, R., R. Morrell, J. Hearn, E. Lundqvist, D. Blackbeard, G. Lindegger, M. Quayle, Y. Sikweyiya, and L. Gottzén. 2015. "Hegemonic Masculinity: Combining Theory and Practice in Gender Interventions." Culture, Health and Sexuality 17 (S2): S112-S127.

Kepe, T. 2010. "'Secrets' that Kill: Crisis, Custodianship and Responsibility in Ritual Male Circumcision in the Eastern Cape Province, South Africa." Social Science and Medicine 70 (5): 729-735. 
Kimmel, M.S. 1994. "Masculinity as Homophobia: Fear, Shame, and Silence in the Construction of Gender Identity." In Theorizing Masculinities, edited by H. Brod, and M. Kaufman, 119-141. Thousand Oaks: Sage Publications.

Kimmel, M.S., and M.A. Messner, eds. 2001. Men's Lives. 5th ed. Boston: Allyn and Bacon. Mandela, N. 1995. Long Walk to Freedom. Boston: Little, Brown.

Mavundla, T.R., F.G. Netswera, F. Toth, B. Bottoman, and S. Tenge. 2010. "How Boys become Dogs: Stigmatization and Marginalization of Uninitiated Xhosa Males in East London, South Africa.” Qualitative Health Research 20 (7): 931-941.

Mda, Z. 2000. The Heart of Redness. Oxford: Oxford University Press.

Mda, Z. 2013. Sometimes there is a Void: Memoirs of an Outsider. Johannesburg: Penguin.

Mgqolozana, T. 2009. A Man Who is Not a Man. Scottsville: University of KwaZulu-Natal Press.

Morrell, R. 1998. "Of Boys and Men: Masculinity and Gender in Southern African Studies." Journal of Southern African Studies 24 (4): 605-630.

Msibi, T. 2013. "Homophobic Language and Linguistic Resistance in KwaZulu-Natal, South Africa." In Gender and Language in Sub-Saharan Africa: Tradition, Struggle and Change, edited by L.L. Atanga, S.E. Ellece, L. Litosseliti, and J. Sunderland, 253-274. Amsterdam: John Benjamins.

Narayan, K. 1993. "How Native is a 'Native' Anthropologist?” American Anthropologist 95 (3): 671-686. Ndletyana, M. 2008. African Intellectuals in 19th and early 2oth Century South Africa. Cape Town: HSRC Press.

Ngwane, Z. 2004. "Real Men Awaken their Fathers' Homesteads, the Educated Leave them in Ruins': The Politics of Domestic Reproduction in Post-Apartheid South Africa." In Producing African Futures: Ritual and Reproduction in a Neoliberal Age, edited by B. Weiss, 167-192. Leiden: Brill.

Ntombana, L. 2011. "Should Xhosa Male Initiation be Abolished?" International Journal of Cultural Studies 14 (6): 631-640.

Nxasana, T. 2011. "The Journey of the African as Missionary: The Journal and Selected Writings of the Reverend Tiyo Soga.” English in Africa 38 (2): 61-76.

Nyamnjoh, F.B. 2012a. "Potted Plants in Greenhouses': A Critical Reflection on the Resilience of Colonial Education in Africa." Journal of Asian and African Studies 47 (2): 129154.

Nyamnjoh, F.B. 2012b. "Blinded by Sight: Divining the Future of Anthropology in Africa." Africa Spectrum 47 (2-3): 63-92.

Ortner, S. 1974. "Is Female to Male as Nature is to Culture?" In Woman, Culture and Society, edited by M.Z. Rosaldo, and L. Lamphere, 67-87. Stanford: Stanford University Press. Ougzane, L. 2006. Islamic Masculinities. London: Zed.

Peires, J.B. 1989. The Dead will Arise: Nongqawuse and the Great Xhosa Cattle-Killing Movement of 1856-7. Johannesburg: Jonathan Ball Publishers.

Peltzer, K., and X. Kanta. 2009. "Medical Circumcision and Manhood Initiation Rituals in the Eastern Cape, South Africa: A Post Intervention Evaluation." Culture, Health and Sexuality 11 (1): 83-97. 
Pleck, J. 1987. "The Theory of Male Sex-Role Identity: Its Rise and Fall, 1936 to the Present." In The Making of Masculinities: The New Men's Studies, edited by H. Brod, 21-38. Boston: Allen \& Unwin.

Pogrund, B. 1990. How can Man Die Better: The Life of Robert Sobukwe. Johannesburg: Jonathan Ball. Ratele, K. 2011. "Male Sexualities and Masculinities." In African Sexualities, edited by S. Tamale, 399-419. Cape Town: Pambazuka Press.

Ratele, K. 2013. “Masculinities without Tradition.” Politikon 40 (1): 133-156.

Ross, J.S. 2010. "Sound the Trumpet: An Introduction to the Life and Ministry of Tiyo Soga, 1829-1871." Haddington House Journal, no. 12: 103-119.

"SA Doctors Perform World's First Successful Penis Transplant." SouthAfrica.info, March 16, 2015. http:// www.southafrica.info/about/health/penis-transplant160315.htm\#.V3C5yaKnHrI

Schrock, D., and M. Schwalbe. 2009. "Men, Masculinity, and Manhood Acts." Annual Review of Sociology, no. 35: 277-295.

Soga, J.H. 1931. The amaXhosa: Life and Customs. Alice: Lovedale Press.

Soga, T. 1983. The Journal and Selected Writings of the Reverend Tiyo Soga. Edited by D. Williams. Cape Town: A.A. Balkema.

Swain, J. 2003. "How Young Schoolboys Become Somebody: The Role of the Body in the Construction of Masculinity." British Journal of Sociology of Education 24 (3): 299314.

Swart, S. 2001. "Man, Gun and Horse: Hard Right Afrikaner Masculine Identity in PostApartheid South Africa." In Changing Men in Southern Africa, edited by R. Morrell, 75-89. Pietermaritzburg: University of Natal Press.

Talbot, K., and M. Quayle. 2010. "The Perils of Being a Nice Guy: Contextual Variation in Five Young Women's Constructions of Acceptable Hegemonic and Alternative Masculinities." Men and Masculinities 13 (2): 255-278.

Venter, M.A. 2011. "Some Views of Xhosa Women Regarding the Initiation of their Sons." Koers 76 (3): 559-575.

Vincent, L. 2008. "Boys will be Boys': Traditional Xhosa Male Circumcision, HIV and Sexual Socialisation in Contemporary South Africa." Culture, Health and Sexuality 10 (5): 431-446.

Wacquant, L.J.D. 1995. "Pugs at Work: Bodily Capital and Bodily Labour among Professional Boxers." Body and Society 1 (1): 65-93.

Williams, D. 1978. Umfundisi: A Biography of Tiyo Soga, 1829-1871. Alice: Lovedale Press.

Woodward, K. 2001. "Body Politics: Masculinities in Sport." In Global Masculinities and Manhood, edited by R.L. Jackson, and M. Balaji, 202-221. Urbana: University of Illinois Press. 